\title{
GRUPO DE APOIO E REABILITAÇÃO DE PESSOAS OSTOMIZADAS (GARPO)
}

Márcia Maria Fontão Zago*

O grupo foi formado em 1990; constitui-se de uma equipe multiprofissional e tem como objetivo a assistência, pesquisa e ensino da reabilitação de pessoas ostomizadas.

O grupo promove encontros com pacientes e familiares, mensalmente, na Escola de Enfermagem de Ribeirão Preto da Universidade de São Paulo.

Na primeira $5^{\underline{a}}$ feira de cada mês, às 08:00 horas, acontece o encontro com pessoas colostomizadas, ileostomizadas e urostomizadas.

Na última $5^{\text {a }}$ feira de cada mês, às 14:00 horas, acontece o encontro com pessoas laringectomizadas.

As intervenções com as pessoas ostomizadas são embasadas no ensino de pacientes.

Os encontros são abertos para a população.

*Assistente do Departamento de Enfermagem Geral e Especializada da Escola de Enfermagem de Ribeirão Preto da Universidade de São Paulo. 